J-SISKO TECH

Jurnal Teknologi Sistem Informasi dan Sistem Komputer TGD

P:ISSN : 2621-8976 E-ISSN : 2615-5133

Vol.3, No.1, Januari 2020, pp.163-181

\title{
Analisis Data Mining Untuk Strategi Promosi Produk Kosmetik Di Wardah Kosmetik Menggunakan Metode Apriori
}

\author{
*Suardi Yakub, Syafitriani \\ Program Studi Sistem Informasi, STMIK Triguna Dharma \\ Email : yakubsuardi@yahoo.co.id
}

\begin{abstract}
Abstrak
Salah satu cara yang dilakukan sebuah perusahaan atau pengusaha dalam memberikan pelayanan dan informasi kepada konsumen sangat mempegaruhi minat pelanggan dalam membeli produk dapat meningkatkan penjualan. Penerapan produk terkait yang dipasangkan dengan produk yang akan dibeli konsumen, mungkin juga akan mempengaruhi konsumen membeli produk yang berkaitan dengan produk yang akan dibeli. Dalam ha ini analisis strategi promosi dengan menggunakan algoritma apriori sangat dibutuhkan.

Data mining merupakan proses analisa data untuk menemukan susatu pola dari kumpulan data tersebut. Data mining mampu menganalisa data besar menjadi informasi berupa pola yang mempunyai arti bagi pendukungkeputusan. Salah satu teknik data mining yang dapatdigunakan adalah asociation data mining. Salah satu teknik data mining yang digunakan untuk merancang strategi promsi penjualan yang efektif dengan memanfaatkan data transaksi yang tersedia pada perusahaan atau yang kerap disebut analisa keranjang pasar. Teknik ini bertujuan untuk menemukan pola pembelian dalam satu transaksi dari data yang umumnya sangat besar. Konsep data mining akan memberikan penyelesaian terhadap masalah bisnis. PT Wardah Kosmetik dalam hal penentuan item paket yang lebih menarik. Pada penelitian ini peneliti menggunakan algoritma apriori dengan teknik association rule dimana hasil implementasi itemset didapatkan dari nilai support dan nilai confidence.
\end{abstract}

Kata Kunci : Data Mining, Algoritma Apriori, Promosi Penjualan, Association Rule

\begin{abstract}
One of the ways a company or entrepreneur in providing services and information to consumers greatly affect the customer's interest in buying products can increase sales. The application of related products that are paired with products to be purchased by consumers, might also influence consumers to buy products related to the products to be purchased. In this case the promotion strategy analysis using a priori algorithm is needed.

Data mining is the process of analyzing data to find patterns in a set of data. Data mining is able to analyze big data into information in the form of patterns that have meaning for decision supporters. One data mining technique that can be used is data mining associations. One of the data mining techniques used to design effective sales promotion strategies is to utilize transaction data available to companies or what is often called market basket analysis. This technique aims to find purchase patterns in a single transaction from generally large data. The concept of data mining will provide solutions to business problems. PT Wardah Kosmetik in terms of determining more attractive package items. In this study, researchers used a priori
\end{abstract}


algorithm with the association rule technique where the results of the itemset implementation were obtained from the support and confidence values.

Keywords: Data Mining, Apriori Algorithms, Sales Promotion, Association Rule

\section{Pendahuluan}

Produk kosmetik pada Wardah tidak semua diminati oleh konsumen, ada beberapa produk yang sangat diminati dan ada juga yang kurang diminati, ditambah lagi persaingan produk sejenis oleh perusahan kosmetik lain. Karena adanya beberapa produk kosmetik yang kurang diminati oleh konsumen yang mengakibatkan penumpukan item, maka masalah tersebut sangat berpengaruh pada penurunan omset penjualan dan mengakibatkan penurunan keuntungan pada perusahaan. Untuk mengatasi permasalahan tersebut maka dapat dilakukan dengan memberikan kombinasi promo menggunakan algoritma Data Mining.

Data Mining adalah suatu istilah yang digunakan untuk menguraikan pengetahuan didalam database atau sering disebut dengan Knowledge Discovery in Database (KDD). Dari definisi Data Mining yang luas banyak jenis tekhnik analisa yang dapat digunakan dalam Data Mining.

Ada berbagai Algoritma dalam Data Mining yang dapat digunakan dalam melakukan analisis strategi promosi pada Wardah Kosmetik salah satunya adalah Algoritma Apriori. Apriori merupakan algoritma untuk mencari pola hubungan antar satu atau lebih item dalam satu database.

\section{LANDASAN TEORI}

\subsection{Data Mininng}

Data mining adalah suatu istilah yang digunakan untuk menemukan pengetahuan yang tersembunyi di dalam database. Dalam perkembangan data mining memiliki banyak defenisi yang cukup beragam sehingga data mining untuk menambah ilmu pengetahuan.

Menurut LufioAdi (2016:180) "Promosi penjualan adalah semua kegiatan yang dimaksud untuk meningkatkan arus barang atau jasa dari produsen sampai pada penjualan akhirnya. Promosi penjualan terdiri atas brosur lembar informasi dan lain-lain".

Menurut Kesuma dkk (2018:30) "Penjualan adalah penerimaan yang diperoleh dari pengiriman barang dagangan atau dari penyerahan pelayanan dalam bursa sebagai barang pertimbangan. Pertimbangan ini dapat dalam bentuk tunai peralatan kas atau harta lainnya".

Menurut Karim (2019:102-113) "Promosi penjualan adalah kegiatan komunikasi antara perusahaaan dan konsumen sebagai usaha untuk mempengaruhi konsumen dalam kegiatan pembeliaan sesuatu keinginan dan kebutuhannya".

\subsection{Proses Knowledge Discovery in Database (KDD)}

Istilah data mining dan Knowledge Discovery in Database (KDD) sering kali digunakan secara bergantian untuk menjelaskan proses penggalian informasi tersembunyi dalam suatu basis data yang besar. Sebenarnya kedua istilah tersebut memiliki konsep yang berbeda, tetapi berkaitan satu sama lain. Dan salah satu tahapan dalam keseluruhan KDD adalah data mining. 


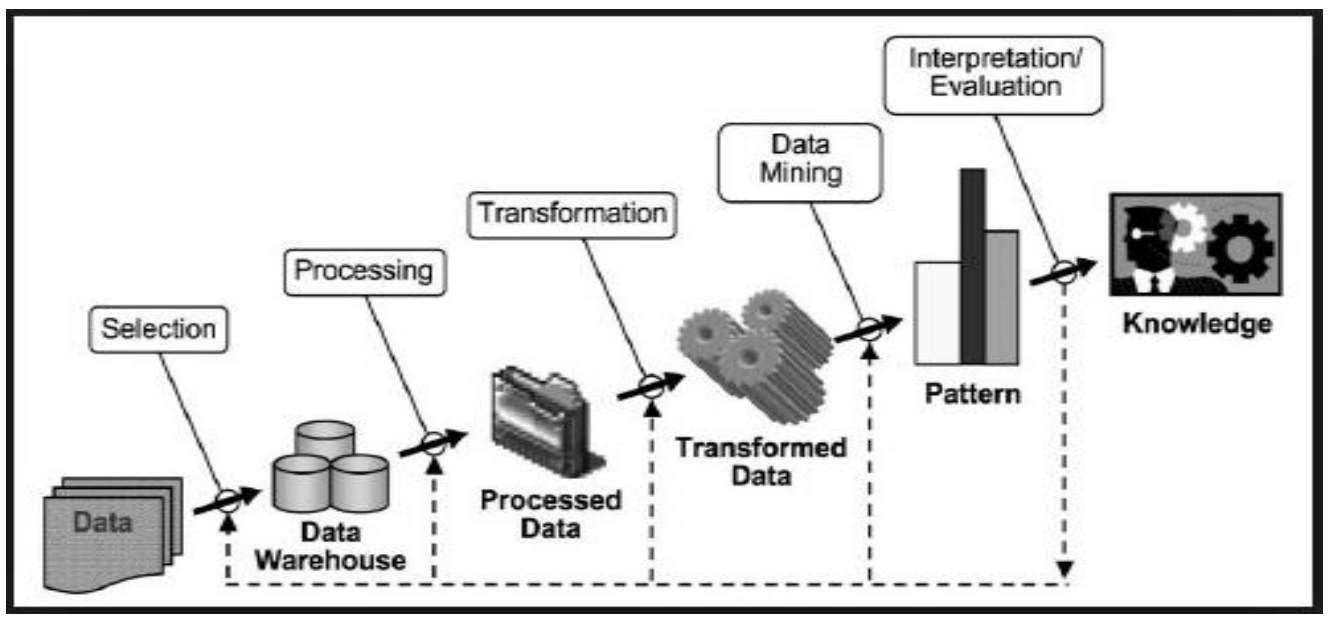

Gambar 2.1 Proses Knowledge Discovery in Database

\section{Data Selection}

KDD secara garis besar dapat dijelaskan sebagai berikut :

Pemilihan (seleksi) data dari sekumpulan data operasional perlu dilakukan sebelum tahap penggalian informasi dalam KDD dimulai. Data hasil seleksi yang digunakan untuk proses data mining, disimpan dalam suatu berkas, terpisah dari basis data operasional.

2. Pre-processing/ Cleaning

Sebelum proses data mining dapat dilaksanakan, perlu dilakukan proses cleaning pada data yang menjadi fokus KDD. Proses cleaning mencakup antara lain membuang duplikasi data, memeriksa data yang inkonsisten, dan memperbaiki kesalahan pada data, seperti kesalahan cetak (tipografi). Juga dilakukan proses "memperkaya" data yang sudah ada dengan data atau informasi lain yang relevan dan diperlukan untuk KDD, seperti data atau informasi eksternal.

3. Transformation

Coding adalah proses transformasi pada data yang telah dipilih, sehingga data tersebut sesuai untuk proses data mining. Proses coding dalam KDD merupakan proses kreatif dan sangat tergantung pada jenis atau pola informasi yang akan dicari dalam basis data.

4. Data Mining

Data mining adalah proses mencari pola atau informasi menarik dalam data terpilih dengan menggunakan teknik atau metode tertentu. Teknik metode atau algoritma dalam data mining sangat bervariasi. Pemilihan metode atau algoritma yang tepat sangat bergantung pada tujuan dan proses KDD secara keseluruhan.

5. Interpretation/Evaluation

Pola informasi yang dihasilkan dari proses data mining perlu ditampilkan dalam bentuk yang mudah dimengerti oleh pihak yang berkepentingan. Tahap ini merupakan bagian dari proses KDD yang disebut interpretation. Tahap ini mencakup pemeriksaan apakah pola atau informasi yang ditemukan bertentangan dengan fakta atau hipotesis yang ada sebelumnya.

\subsection{Wardah Kosmetik}

Wardah merupakan salah satu produsen produk kecantikan yang didirikan oleh pasangan suami istri Drs.H. Subakat Had, M.Sc dan Dra. Hj. Nurhayati Subakat, Apt. Perusahaan yang didirikan oleh pasangan suami istri ini bernama PT Pusaka Tradisi lbu yang 
didirikan pada tanggal 28 Februari 1985 dan perusahaan ini berganti nama menjadi PT Paragon Technologi and Innovation pada tahun 2011. Pada saat itu pendiri melihat masih ada peluang terbuka dan perusahaan ini dimulai dengan sederhana namun sudah diusahakan dengan tata cara yang baik.

Sumber : eprints.ums.ac.id

\subsection{Metode Apriri}

Algoritma apriori adalah termasuk jenis aturan asosiasi pada data mining. Selain apriori, yang termasuk pada golongan ini adalah metode Generalized Rule Induction dan algoritma hash based. Aturan yang menyatakan asosiasi antara beberapa atribut sering disebut affinity analysis atau market basket analysis.

\subsection{UML (Unified Modeling Language)}

Secara fisik, UML adalah sekumpulan spesifikasi yang dikeluarkan oleh OMG. UML terbaru adalah UML 2.3 yang terdiri dari 4 macam spesifikasi, yaitu Diagram Interchange Specification, UML Infrastructure, UML Superstructure, dan Object Constraint Language (OCL). Pada UML 2.3 terdiri dari 13 macam diagram yang dikelompokkan dalam 3 kategori. Berikut ini penjelasan singkat dari pembangian keategori tersebut :

1. Structure diagrams yaitu kumpulan diagram yang digunakan untuk menggambarkan suatu struktur statis dari sistem yang dimodelkan.

2. Behavior diagrams yaitu kumpulan diagram yang digunakan untuk lebih bisa menggambarkan kelakuan sistem atau rangkaian perubahan yang terjadi pada sebuah sistem.

3. Interaction diagrams yaitu kumpulan diagram yang digunakan untuk menggambarkan interaksi sistem dengan sistem lain maupun interaksi antar subsistem pada suatu sistem.

\section{ANALISIS DAN PERANCANGAN \\ 3.1 Analisa Permasalahan}

Analisis sistem merupakan kebutuhan yang difokuskan pada pemahaman tentang informasi, fungsi, dan performansi perangkat lunak. Ada beberapa tahapan yang akan dilaksanakan pada analisis sistem dalam penelitian ini yakni analisis permasalahan dan analisis dalam data mining.

Mengidentifikasi masalah dimulai dengan mengkaji subyek permasalahan yang ada. Adapun masalah yang dihadapi oleh PT. Paragon Technologi and Innovation adalah menentukan item yang sesuai untuk dijadikan paket promosi, ada pun metode untuk menyelesaikan permasalahan ini yaitu menggunakan Metode Apriori dengan teknik Association Rule.

Setiap data akan dihitung menggunakan metode Association Rule dan akan mendapatkan pengelompokan dari setiap jenis kosmetik yang telah ditentukan. Sehingga akan didapat kesimpulan berupa penggabungan antara beberapa jenis yang akan dipasangkan mulai dari jenis kosmetik yang kurang diminati hingga yang paling diminati oleh costumer.

Oleh sebab itu itu perusahaan memerlukan sistem untuk mengolah data yang dapat menghasilkan data penjualan kosmetik yang paling sering di beli, sehingga produk kosmetik yang paling sering di beli tersebut dapat menjadi acuan untuk mengembangkan strategi pemasaran produk tersebut pada konsumen. 
No Transaksi

01

02

03

04

05

06

07

08

09

10

11

12

13

14

15

16

17

18

19

20

21

22

23

24

25

26

27

28

29

30
Tgl

Transaksi

13/01/19

$14 / 01 / 19$

$15 / 01 / 19$

$16 / 01 / 19$

$17 / 01 / 19$

$18 / 01 / 19$

$19 / 01 / 19$

20/01/19

$15 / 02 / 19$

$16 / 02 / 19$

$17 / 02 / 19$

$18 / 02 / 19$

$19 / 02 / 19$

$20 / 02 / 19$

$15 / 03 / 19$

$16 / 03 / 19$

$17 / 03 / 19$

$18 / 03 / 19$

$19 / 03 / 19$

20/03/19

$21 / 03 / 19$

$22 / 03 / 19$

23/03/19

$24 / 03 / 19$

$25 / 03 / 19$

$26 / 03 / 19$

27/03/19

$28 / 03 / 19$

$29 / 03 / 19$

$30 / 03 / 19$
Tabel.1.Data Transaksi

\section{Data Transaksi Penjualan}

Lipstik, Micellar water, Serum, Shampoo, BB

Cream

Cream wajah, Handbody, Shampoo, Blush on

Bedak, Micellar water, DD cream, Shampoo, BB

cream

Bedak, DD cream,Body serum, BB cream

Lisptik, Sabun wajah, Cream wajah, Handbody, Shampoo

Cream wajah, Handbody, Foundation liquid

Lipstik, Toner, Micellar water, Serum, Shampoo,

Bedak, Lipstik, Micellar water,

Lip matte, Blush on

Bedak, DD cream, Body serum, Shampoo, BB cream

Cream wajah, Handbody, BB cream

Lipstik, Shampoo,

Lipstik, Cream wajah, Serum, BB cream

Bedak, Sabun wajah, Micellar water, DD cream,

Body serum, BB cream

Lipstik, Seru, Shampoo

Sabun wajah, Lip matte

Cream wajah, Serum, Body serum, Blush on

Bedak, Lipstik, BB cream

Bedak, Cream wajah, Micellar water, Handbody, Body serum, BB cream

Toner, Micellar water, Shampoo

Lipstik, Toner, Serum, Shampoo

Bedak, Sabun wajah, Body serum, BB cream

Lipstik, Micellar water, Serum, Shampoo

Lip matte, Foundation liquid

Lipstik, Sabun wajah, Toner, Serum, Shampoo

Bedak, Cream wajah, Handbody, Body serum, BB cream

Micellar water, Shampoo

Sabun wajah, Toner, Body serum, Foundation liquid, BB cream

Bedak, Toner, Shampoo, BB cream

Lipstik, Cream wajah, Serum, Funndation liquid

Sumber : Wardah Kosmetik 


\subsubsection{Data Produk}

Identifikasi data dilakukan setelah data terkumpul dan sesuai dengan kebutuhan sistem ini. Oleh sebab itu, untuk menghasilkan kesimpulan berdasarkan aturan (rule) pada analisis data diperlukan data transaksi yang telah dibeli konsumen. Analisis data tersebut dilakukan berdasarkan teknik aturan asosiasi menggunakan algoritma apriori dengan beberapa iterasi atau langkah-langkah. Data yang diambil merupakan data transaksi pembelian produk dalam kurun waktu 3 bulan yaitu pada bulan Januari s/d Maret 2019 pada Wardah Kosmetik. Data tersebut adalah data sample dari data transaksi sebanyak 30 transaksi dan dapat dilihat pada tabel data transaksi.

\section{Tabel 3.1.Kode Produk}

$P 0001$
$P 0002$
$P 0003$
$P 0004$
$P 0005$
$P 0006$
$P 0007$
$P 0008$
$P 0009$
$P 0010$
$P 0011$
$P 0012$
$P 0013$
$P 0014$
$P 0015$

Tabel 3.1 Data Produk

$$
\begin{gathered}
\text { Tabel 3.2.Jenis } \\
\text { Produk }
\end{gathered}
$$

Bedak
Lipstik
Sabun Wajah
Cream Wajah
Toner
Lip matte
Micellar water
DD cream
Serum
Handbody
Body serum
Shampoo
Foundation Liquid
Blush on
BB cream

\subsubsection{Analisis Pencarian Pola Frekuensi Tinggi}

Dari tabel 3.1 Misalkan ada 30 transaksi dan kemudian dilakukan pencarian nilai Support Item dengan rumus:

$$
\operatorname{Support}(A)=\frac{\text { Jumlah Transaksi Menggandung A }}{\text { Total Transaksi }} \times 100 \%
$$

\begin{tabular}{|c|c|c|c|}
\hline No & Kode Item & $\begin{array}{c}\text { Frekuensi } \\
\text { Kemunculan }\end{array}$ & Support \\
\hline 1 & Tabel 3.3. Bedak & 10 & $\begin{array}{c}(10 / 30) \times 100 \%= \\
33 \%\end{array}$ \\
\hline 2 & Tabel 3.4. & 11 & $\begin{array}{c}(11 / 30) \times 100 \%= \\
36 \%\end{array}$ \\
\hline 3 & Tabel 3.5. Sabun wajah & 6 & $(6 / 30) \times 100 \%=20 \%$ \\
\hline
\end{tabular}

Mencari calon 1 itemset dengan nilai support sebagai berikut :

Tabel 3.2 Transaksi 1 Itemset 


\begin{tabular}{|c|c|c|c|}
\hline 4 & Tabel 3.6. Cream wajah & 9 & $(9 / 30) \times 100 \%=30 \%$ \\
\hline 5 & Tabel 3.7. Toner & 6 & $(6 / 30) \times 100 \%=20 \%$ \\
\hline 6 & Tabel 3.8. Lip matte & 3 & $(3 / 30) \times 100 \%=10 \%$ \\
\hline 7 & Tabel 3.9. Micellar water & 9 & $(9 / 30) \times 100 \%=30 \%$ \\
\hline 8 & Tabel 3.10. DD cream & 4 & $(4 / 30) \times 100 \%=13 \%$ \\
\hline 9 & Tabel 3.11. Serum & 8 & $(8 / 30) \times 100 \%=26 \%$ \\
\hline 10 & Tabel 3.12. Handbody & 6 & $(6 / 30) \times 100 \%=20 \%$ \\
\hline 11 & Tabel 3.13. Body serum & 8 & $(8 / 30) \times 100 \%=26 \%$ \\
\hline 12 & Tabel 3.14. Shampoo & 14 & $\begin{array}{c}(14 / 30) \times 100 \%= \\
46 \%\end{array}$ \\
\hline 13 & $\begin{array}{c}\text { Tabel 3.15. Foundation } \\
\text { Liquid }\end{array}$ & 3 & $(3 / 30) \times 100 \%=10 \%$ \\
\hline 14 & Tabel 3.16. Blush on & 3 & $(3 / 30) \times 100 \%=10 \%$ \\
\hline 15 & Tabel 3.17. BB cream & 13 & $\begin{array}{c}(13 / 30) \times 100 \%= \\
43 \%\end{array}$ \\
\hline
\end{tabular}

Berdasarkan tabel 3.2 yang berisi item-item dengan nilai support yang dimilikinya dengan menetapkan minimum support $\leq 20 \%$, maka item - item yang memiliki nilai support kurang dari $20 \%$ harus dieliminasi. Hasil dapat terlihat pada tabel 3.3.

Tabel 3.3 Nilai Support 1 Itemset Memenuhi Minimum Support \& Eliminasi

\begin{tabular}{|c|c|c|c|}
\hline No & Kode Item & $\begin{array}{c}\text { Frekuensi } \\
\text { Kemunculan }\end{array}$ & Support \\
\hline 1 & Tabel 3.18. Bedak & 10 & $33.33 \%$ \\
\hline 2 & Tabel 3.19. Lipstik & 11 & $36.66 \%$ \\
\hline 3 & Tabel 3.20. Sabun wajah & 6 & $20.00 \%$ \\
\hline 4 & Tabel 3.21. Cream wajah & 9 & $30.00 \%$ \\
\hline 5 & Tabel 3.22. Toner & 6 & $20.00 \%$ \\
\hline 6 & Tabel 3.23. Micellar water & 9 & $30.00 \%$ \\
\hline 7 & Tabel 3.24. Serum & 8 & $26.67 \%$ \\
\hline 8 & Tabel 3.25. Handbody & 6 & $20.00 \%$ \\
\hline 9 & Tabel 3.26. Body Serum & 8 & $26.67 \%$ \\
\hline 10 & Tabel 3.27. Shampoo & 14 & $46.67 \%$ \\
\hline 11 & Tabel 3.28. BB cream & 13 & $43.33 \%$ \\
\hline
\end{tabular}

\subsubsection{Pembentukan Pola Kombinasi Dua Item Set}

Setelah mengetahui jumlah kemunculan 1 itemset, selanjutnya dengan membahas jumlah kemunculan 2 itemset dari data itemset yang telah difilter berdasarkan minsupport, seperti berikut ini :

Support $(\mathrm{A}, \mathrm{B})=$ Jumlah Transaksi Menggandung Bedak, Lipstik

Sehingga

\section{Total Transaksi} x $100 \%$

$$
\text { Support }(A)=\quad \stackrel{2}{-} \times 100 \%=6,67 \%
$$


30

Tabel 3.4 Pola Kombinasi 2-Itemset dengan Nilai Support

\begin{tabular}{|c|c|c|c|}
\hline No & Pola 2 Item Set & $\begin{array}{c}\text { Frekuensi } \\
\text { Kemunculan }\end{array}$ & Nilai Support \\
\hline 1 & Bedak, Lipstik & 2 & $(2 / 30) \times 100 \%=6.67 \%$ \\
\hline 2 & Bedak, Sabun wajah & 2 & $(2 / 30) \times 100 \%=6.67 \%$ \\
\hline 3 & Bedak, Cream wajah & 2 & $(2 / 30) \times 100 \%=6.67 \%$ \\
\hline 4 & Bedak, Toner & 1 & $(1 / 30) \times 100 \%=3.33 \%$ \\
\hline 5 & Bedak, Lip matte & 0 & $(0 / 30) \times 100 \%=0.00 \%$ \\
\hline 6 & Bedak, Micellar water & 4 & $(4 / 30) \times 100 \%=13.33 \%$ \\
\hline 7 & Bedak, DD cream & 4 & $(4 / 30) \times 100 \%=13.33 \%$ \\
\hline 8 & Bedak, Serum & 0 & $(0 / 30) \times 100 \%=0.00 \%$ \\
\hline 9 & Bedak, Handbody & 2 & $(2 / 30) \times 100 \%=6.67 \%$ \\
\hline 10 & Bedak, Body serum & 6 & $(6 / 30) \times 100 \%=20.00 \%$ \\
\hline 11 & Bedak, Shampoo & 3 & $(3 / 30) \times 100 \%=10.00 \%$ \\
\hline 12 & $\begin{array}{l}\text { Bedak, Foundation } \\
\text { liquid }\end{array}$ & 0 & $(0 / 30) \times 100 \%=0.00 \%$ \\
\hline 13 & Bedak, Blush on & 0 & $(0 / 30) \times 100 \%=0.00 \%$ \\
\hline 14 & Bedak, BB cream & 9 & $(0 / 30) \times 100 \%=30.00 \%$ \\
\hline 15 & Lipstik, Sabun wajah & 2 & $(2 / 30) \times 100 \%=6.67 \%$ \\
\hline 16 & Lipstik, Cream wajah & 3 & $(3 / 30) \times 100 \%=10.00 \%$ \\
\hline 17 & Lipstik, Toner & 3 & $(3 / 30) \times 100 \%=10.00 \%$ \\
\hline 18 & Lipstik, Lip matte & 0 & $(0 / 30) \times 100 \%=0.00 \%$ \\
\hline 19 & Lipstik, Micellar water & 4 & $(4 / 30) \times 100 \%=13.33 \%$ \\
\hline 20 & Lipstik, DD cream & 0 & $(0 / 30) \times 100 \%=0.00 \%$ \\
\hline 21 & Lipstik, Serum & 8 & $(8 / 30) \times 100 \%=26.67 \%$ \\
\hline 22 & Lipstik, Handbody & 1 & $(1 / 30) \times 100 \%=3.33 \%$ \\
\hline 23 & Lipstik, Body serum & 0 & $(0 / 30) \times 100 \%=0.00 \%$ \\
\hline 24 & Lipstik, Shampoo & 8 & $(8 / 30) \times 100 \%=26.67 \%$ \\
\hline 25 & $\begin{array}{l}\text { Lipstik, Foundation } \\
\text { liquid }\end{array}$ & 1 & $(1 / 30) \times 100 \%=3.33 \%$ \\
\hline 26 & Lipstik, Blush on & 0 & $(0 / 30) \times 100 \%=0.00 \%$ \\
\hline 27 & Lipstik, BB ceam & 3 & $(3 / 30) \times 100 \%=10.00 \%$ \\
\hline 28 & $\begin{array}{c}\text { Sabun wajah, Cream } \\
\text { wajah }\end{array}$ & 1 & $(1 / 30) \times 100 \%=3.33 \%$ \\
\hline 29 & Sabun wajah, Toner & 2 & $(2 / 30) \times 100 \%=6.67 \%$ \\
\hline 30 & $\begin{array}{l}\text { Sabun wajah, Lip } \\
\text { matte }\end{array}$ & 1 & $(1 / 30) \times 100 \%=3.33 \%$ \\
\hline 31 & $\begin{array}{l}\text { Sabun wajah, Micellar } \\
\text { water }\end{array}$ & 1 & $(1 / 30) \times 100 \%=3.33 \%$ \\
\hline 32 & $\begin{array}{c}\text { Sabun wajah, DD } \\
\text { cream }\end{array}$ & 1 & $(1 / 30) \times 100 \%=3.33 \%$ \\
\hline 33 & Sabun wajah, Serum & 1 & $(1 / 30) \times 100 \%=3.33 \%$ \\
\hline 34 & Sabun wajah, & 1 & $(1 / 30) \times 100 \%=3.33 \%$ \\
\hline
\end{tabular}

J-SISKO TECH Vol. 3, No. 1, 2020 : 163-181 


\begin{tabular}{|c|c|c|c|}
\hline & Handbody & & \\
\hline 35 & $\begin{array}{c}\text { Sabun wajah, Body } \\
\text { serum }\end{array}$ & 3 & $(3 / 30) \times 100 \%=10.00 \%$ \\
\hline 36 & $\begin{array}{l}\text { Sabun wajah, } \\
\text { Shampoo }\end{array}$ & 2 & $(2 / 30) \times 100 \%=6.67 \%$ \\
\hline 37 & $\begin{array}{l}\text { Sabun wajah, } \\
\text { Foundation liquid }\end{array}$ & 1 & $(1 / 30) \times 100 \%=3.33 \%$ \\
\hline 38 & Sabun wajah, Blush on & 0 & $(0 / 30) \times 100 \%=0.00 \%$ \\
\hline 39 & $\begin{array}{l}\text { Sabun wajah, BB } \\
\text { cream }\end{array}$ & 3 & $(3 / 30) \times 100 \%=10.00 \%$ \\
\hline 40 & Lip matte, Toner & 0 & $(0 / 30) \times 100 \%=0.00 \%$ \\
\hline 41 & $\begin{array}{l}\text { Cream wajah, Lip } \\
\text { matte }\end{array}$ & 0 & $(0 / 30) \times 100 \%=0.00 \%$ \\
\hline 42 & $\begin{array}{c}\text { Cream wajah, Micellar } \\
\text { water }\end{array}$ & 1 & $(1 / 30) \times 100 \%=3.33 \%$ \\
\hline 43 & $\begin{array}{c}\text { Cream wajah, DD } \\
\text { cream }\end{array}$ & 0 & $(0 / 30) \times 100 \%=0.00 \%$ \\
\hline 44 & Cream wajah, Serum & 2 & $(2 / 30) \times 100 \%=6.67 \%$ \\
\hline 45 & $\begin{array}{l}\text { Cream wajah, } \\
\text { Handbody }\end{array}$ & 7 & $(7 / 30) \times 100 \%=23.33 \%$ \\
\hline 46 & $\begin{array}{l}\text { Cream wajah, Body } \\
\text { serum }\end{array}$ & 3 & $(3 / 30) \times 100 \%=10.00 \%$ \\
\hline 47 & $\begin{array}{l}\text { Cream wajah, } \\
\text { Shampoo }\end{array}$ & 2 & $(2 / 30) \times 100 \%=6.67 \%$ \\
\hline 48 & $\begin{array}{c}\text { Cream wajah, } \\
\text { Foundation liquid }\end{array}$ & 2 & $(2 / 30) \times 100 \%=6.67 \%$ \\
\hline 49 & $\begin{array}{l}\text { Cream wajah, Blush } \\
\text { on }\end{array}$ & 2 & $(2 / 30) \times 100 \%=6.67 \%$ \\
\hline 50 & $\begin{array}{l}\text { Cream wajah, BB } \\
\text { cream }\end{array}$ & 4 & $(4 / 30) \times 100 \%=13.33 \%$ \\
\hline 51 & Toner, Lip matte & 0 & $(0 / 30) \times 100 \%=0.00 \%$ \\
\hline 52 & Toner, Micellar water & 2 & $(2 / 30) \times 100 \%=6.67 \%$ \\
\hline 53 & Toner, DD cream & 0 & $(0 / 30) \times 100 \%=0.00 \%$ \\
\hline 54 & Toner, Serum & 3 & $(3 / 30) \times 100 \%=10.00 \%$ \\
\hline 55 & Toner, Handbody & 0 & $(0 / 30) \times 100 \%=0.00 \%$ \\
\hline 56 & Toner, Body serum & 1 & $(1 / 30) \times 100 \%=3.33 \%$ \\
\hline 57 & Toner, Shampoo & 5 & $(5 / 30) \times 100 \%=16.67 \%$ \\
\hline 58 & $\begin{array}{l}\text { Toner, Foundation } \\
\text { liqud }\end{array}$ & 1 & $(1 / 30) \times 100 \%=3.33 \%$ \\
\hline 59 & Toner, Blush on & 0 & $(0 / 30) \times 100 \%=0.00 \%$ \\
\hline 60 & Toner, BB cream & 2 & $(2 / 30) \times 100 \%=6.67 \%$ \\
\hline 61 & $\begin{array}{l}\text { Lip matte, Micellar } \\
\text { water }\end{array}$ & 0 & $(0 / 30) \times 100 \%=0.00 \%$ \\
\hline 62 & Lip matte, DD cream & 0 & $(0 / 30) \times 100 \%=0.00 \%$ \\
\hline 63 & Lip matte, Serum & 0 & $(0 / 30) \times 100 \%=0.00 \%$ \\
\hline 64 & Lip matte, Handbody & 0 & $(0 / 30) \times 100 \%=0.00 \%$ \\
\hline 65 & Lip matte, Body serum & 0 & $(0 / 30) \times 100 \%=0.00 \%$ \\
\hline
\end{tabular}




\begin{tabular}{|c|c|c|c|}
\hline 66 & Lip matte, Shampoo & 0 & $(0 / 30) \times 100 \%=0.00 \%$ \\
\hline 67 & $\begin{array}{l}\text { Lip matte, Foundation } \\
\text { liquid }\end{array}$ & 1 & $(1 / 30) \times 100 \%=3.33 \%$ \\
\hline 68 & Lip matte, Blush on & 1 & $(1 / 30) \times 100 \%=3.33 \%$ \\
\hline 69 & Lip matte, BB cream & 0 & $(0 / 30) \times 100 \%=0.00 \%$ \\
\hline 70 & $\begin{array}{l}\text { Micellar water, DD } \\
\text { cream }\end{array}$ & 2 & $(2 / 30) \times 100 \%=6.67 \%$ \\
\hline 71 & Micellar water, Serum & 3 & $(3 / 30) \times 100 \%=10.00 \%$ \\
\hline 72 & $\begin{array}{l}\text { Micellar water, } \\
\text { Handbody }\end{array}$ & 1 & $(1 / 30) \times 100 \%=3.33 \%$ \\
\hline 73 & $\begin{array}{l}\text { Micellar water, Body } \\
\text { serum }\end{array}$ & 2 & $(2 / 30) \times 100 \%=6.67 \%$ \\
\hline 74 & $\begin{array}{l}\text { Micellar water, } \\
\text { Shampoo }\end{array}$ & 6 & $(6 / 30) \times 100 \%=20.00 \%$ \\
\hline 75 & $\begin{array}{l}\text { Micellar water, } \\
\text { Foundation liquid }\end{array}$ & 0 & $(0 / 30) \times 100 \%=0.00 \%$ \\
\hline 76 & $\begin{array}{c}\text { Micellar water, Blush } \\
\text { on }\end{array}$ & 0 & $(0 / 30) \times 100 \%=0.00 \%$ \\
\hline 77 & $\begin{array}{l}\text { Micellar water, BB } \\
\text { cream }\end{array}$ & 4 & $(4 / 30) \times 100 \%=13.33 \%$ \\
\hline 78 & DD cream, Serum & 0 & $(0 / 30) \times 100 \%=0.00 \%$ \\
\hline 79 & DD cream, Handbody & 0 & $(0 / 30) \times 100 \%=0.00 \%$ \\
\hline 80 & $\begin{array}{l}\text { DD cream, Body } \\
\text { serum }\end{array}$ & 3 & $(3 / 30) \times 100 \%=10.00 \%$ \\
\hline 81 & DD cream, Shampoo & 2 & $(2 / 30) \times 100 \%=6.67 \%$ \\
\hline 82 & $\begin{array}{l}\text { DD cream, Foundation } \\
\text { liquid }\end{array}$ & 0 & $(0 / 30) \times 100 \%=0.00 \%$ \\
\hline 83 & DD cream, Blush on & 0 & $(0 / 30) \times 100 \%=0.00 \%$ \\
\hline 84 & DD cream, BB cream & 4 & $(4 / 30) \times 100 \%=13.33 \%$ \\
\hline 85 & Serum, Handbody & 0 & $(0 / 30) \times 100 \%=0.00 \%$ \\
\hline 86 & Serum, Body serum & 0 & $(0 / 30) \times 100 \%=0.00 \%$ \\
\hline 87 & Serum, Shampoo & 6 & $(6 / 30) \times 100 \%=20.00 \%$ \\
\hline 88 & $\begin{array}{l}\text { Serum, Foundation } \\
\text { liquid }\end{array}$ & 1 & $(1 / 30) \times 100 \%=3.33 \%$ \\
\hline 89 & Serum, Blush on & 0 & $(0 / 30) \times 100 \%=0.00 \%$ \\
\hline 90 & Serum, BB cream & 2 & $(2 / 30) \times 100 \%=6.67 \%$ \\
\hline 91 & $\begin{array}{c}\text { Handbody, Body } \\
\text { serum }\end{array}$ & 3 & $(3 / 30) \times 100 \%=10.00 \%$ \\
\hline 92 & Handbody, Shampoo & 2 & $(2 / 30) \times 100 \%=6.67 \%$ \\
\hline 93 & $\begin{array}{l}\text { Handbody, Liquid } \\
\text { foundation }\end{array}$ & 1 & $(1 / 30) \times 100 \%=3.33 \%$ \\
\hline 94 & Handbody, Bush on & 2 & $(2 / 30) \times 100 \%=6.67 \%$ \\
\hline 95 & Handbody, BB cream & 3 & $(3 / 30) \times 100 \%=10.00 \%$ \\
\hline 96 & Body serum, Shampoo & 1 & $(1 / 30) \times 100 \%=3.33 \%$ \\
\hline 97 & $\begin{array}{c}\text { Body serum, } \\
\text { Foundation liquid }\end{array}$ & 1 & $(1 / 30) \times 100 \%=3.33 \%$ \\
\hline
\end{tabular}

J-SISKO TECH Vol. 3, No. 1, 2020 : 163-181 


\begin{tabular}{|c|c|c|c|}
98 & Body serum, Blush on & 1 & $(1 / 30) \times 100 \%=3.33 \%$ \\
\hline 99 & $\begin{array}{c}\text { Body serum, BB } \\
\text { cream }\end{array}$ & 7 & $(7 / 30) \times 100 \%=23.33 \%$ \\
\hline 100 & $\begin{array}{c}\text { Shampoo, Foundation } \\
\text { liquid }\end{array}$ & 0 & $(0 / 30) \times 100 \%=0.00 \%$ \\
\hline 101 & Shampoo, Blush on & 1 & $(1 / 30) \times 100 \%=3.33 \%$ \\
\hline 102 & Shampoo, BB cream & 4 & $(4 / 30) \times 100 \%=13.33 \%$ \\
\hline 103 & $\begin{array}{c}\text { Liquid foundation, } \\
\text { Blush on }\end{array}$ & 0 & $(0 / 30) \times 100 \%=0.00 \%$ \\
\hline 104 & $\begin{array}{c}\text { Liquid foundation, BB } \\
\text { cream }\end{array}$ & 1 & $(1 / 30) \times 100 \%=3.33 \%$ \\
\hline 105 & Blush on, BB cream & 0 & $(0 / 30) \times 100 \%=0.00 \%$ \\
\hline
\end{tabular}

Dengan menetapkan minimum support $\leq 20 \%$, maka item - item yang memiliki nilai support kurang dari $20 \%$ akan dieliminasi kembali. Hasil dapat terlihat pada tabel berikut ini:

Dengan menetapkan minimum support $\geq 20 \%$, maka item - item yang memiliki nilai support kurang dari $20 \%$ dihilangkan. Hasil dapat terlihat pada tabel berikut ini:

Tabel 3.5 Hasil nilai support 2 itemset dengan ketentuan minimum support \& eliminasi

\begin{tabular}{|c|c|c|c|}
\hline No & Pola 2 Item Set & $\begin{array}{c}\text { Frekuensi } \\
\text { Kemuncular } \\
\text { A } \cap \text { B }\end{array}$ & Nilai Support \\
\hline 1 & Bedak, Body serum & 6 & $(6 / 30) \times 100 \%=20.00 \%$ \\
\hline 2 & Bedak, BB cream & 9 & $(9 / 30) \times 100 \%=30.00 \%$ \\
\hline 3 & Lipstik, Serum & 8 & $(8 / 30) \times 100 \%=26.67 \%$ \\
\hline 4 & Lipstik, Shampoo & 8 & $(8 / 30) \times 100 \%=26.67 \%$ \\
\hline 5 & $\begin{array}{c}\text { Cream wajah } \\
\text { Handbody }\end{array}$ & 7 & $(7 / 30) \times 100 \%=23.33 \%$ \\
\hline 6 & $\begin{array}{c}\text { Micellar water } \\
\text { Shampoo }\end{array}$ & 6 & $(6 / 30) \times 100 \%=20.00 \%$ \\
\hline 7 & Serum, Shampoo & 6 & $(6 / 30) \times 100 \%=20.00 \%$ \\
\hline 8 & $\begin{array}{c}\text { Body serum, BB } \\
\text { cream }\end{array}$ & 7 & $(7 / 30) \times 100 \%=23.33 \%$ \\
\hline
\end{tabular}

\subsubsection{Perhitungan Nilai Confidence}

Kemudian akan dihitung nilai Confidence dengan aturan minimum confidence $=70 \%$ ditentukan dari setiap kombinasi Item yang terdapat pada tabel 3.5 berdasarkan rumus :

$$
\text { Confidence }(A \cap B)=\frac{\text { Jumlah Transaksi Menggandung A dan B }}{\text { Total Transaksi Mengandung A }} \times 100 \%
$$

Sehingga

Confidence $(A, B)=\frac{6}{10} \quad \times 100 \%=60,00 \%$

Dapat diliat seperti contoh tabel 3.6 sebagai berikut:

Tabel 3.6 Hasil Confidance 


\begin{tabular}{|c|c|c|c|c|}
\hline No & Pola 2 Item Set & $\begin{array}{c}\text { Frekuensi } \\
\text { Kemunculan } \\
\boldsymbol{A}\end{array}$ & 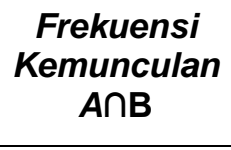 & Nilai Confidance \\
\hline 1 & Bedak, Body serum & 10 & 6 & $\begin{array}{c}(6 / 10) \times 100 \%= \\
60.00 \%\end{array}$ \\
\hline 2 & Body serum, Bedak & 8 & 6 & $(6 / 8) \times 100 \%=75.00 \%$ \\
\hline 3 & Bedak, BB cream & 10 & 9 & $\begin{array}{c}(9 / 10) \times 100 \%= \\
90.00 \%\end{array}$ \\
\hline 4 & BB cream, Bedak & 13 & 9 & $\begin{array}{c}(9 / 13) \times 100 \%= \\
69.23 \%\end{array}$ \\
\hline 5 & Lipstik , serum & 12 & 8 & $\begin{array}{c}(8 / 12) \times 100 \%= \\
66.67 \%\end{array}$ \\
\hline 6 & Serum , Lipstik & 8 & 8 & $\begin{array}{c}(8 / 8) \times 100 \%= \\
100.00 \%\end{array}$ \\
\hline 7 & Lipstik , Shampoo & 12 & 8 & $\begin{array}{c}(8 / 12) \times 100 \%= \\
66.67 \%\end{array}$ \\
\hline 8 & Shampoo, Lipstik & 14 & 8 & $\begin{array}{c}(8 / 14) \times 100 \%= \\
57.14 \%\end{array}$ \\
\hline 9 & $\begin{array}{c}\text { Cream wajah } \\
\text { Handbody }\end{array}$ & 9 & 7 & $(7 / 9) \times 100 \%=77.78 \%$ \\
\hline 10 & $\begin{array}{c}\text { Handbody, Cream } \\
\text { wajah }\end{array}$ & 7 & 7 & $\begin{array}{c}(7 / 7) \times 100 \%= \\
100.00 \%\end{array}$ \\
\hline 11 & $\begin{array}{l}\text { Micelarr water, } \\
\text { Shampoo }\end{array}$ & 9 & 6 & $(6 / 9) \times 100 \%=66.67 \%$ \\
\hline 12 & $\begin{array}{c}\text { Shampoo, Micelarr } \\
\text { water }\end{array}$ & 14 & 6 & $\begin{array}{c}(6 / 14) \times 100 \%= \\
42.86 \%\end{array}$ \\
\hline 13 & Serum , Shampoo & 8 & 6 & $(6 / 8) \times 100 \%=75.00 \%$ \\
\hline 14 & Shampoo, Serum & 14 & 6 & $\begin{array}{c}(6 / 14) \times 100 \%= \\
42.86 \%\end{array}$ \\
\hline 15 & $\begin{array}{l}\text { Body serum, BB } \\
\text { cream }\end{array}$ & 8 & 7 & $(7 / 8) \times 100 \%=87.50 \%$ \\
\hline 16 & $\begin{array}{l}\text { BB cream , Body } \\
\text { serum }\end{array}$ & 13 & 7 & $(7 / 13) \times 100 \% 53.85 \%$ \\
\hline
\end{tabular}

Dengan nilai confidence yang didapat, kemudian hilangkan nilai confidence yang tidak memenuhi ketentuan kurang dari confidence $70 \%$ yaitu sebagai berikut:

Tabel 3.7 Hasil Minimum Confidence

\begin{tabular}{|c|c|c|c|c|}
\hline No & Aturan & $\begin{array}{c}\text { Frekuensi } \\
\text { Kemunculan } \\
\boldsymbol{A}\end{array}$ & $\begin{array}{c}\text { Frekuensi } \\
\text { Kemunculan } \\
\text { AnB }\end{array}$ & $\begin{array}{c}\text { Nilai } \\
\text { Confidanc } \\
\boldsymbol{e}\end{array}$ \\
\hline 1 & Serum , Lipstik & 8 & 8 & $100.00 \%$ \\
\hline 2 & $\begin{array}{c}\text { Handbody, Cream } \\
\text { wajah }\end{array}$ & 7 & 7 & $100.00 \%$ \\
\hline 3 & Bedak, BB cream & 10 & 9 & $90.00 \%$ \\
\hline 4 & $\begin{array}{c}\text { Body serum , BB } \\
\text { cream }\end{array}$ & 8 & 7 & $87.50 \%$ \\
\hline 5 & Cream wajah , & 9 & 7 & $77.78 \%$ \\
\hline
\end{tabular}




\begin{tabular}{|c|c|c|c|c|}
\hline & Handbody & & & \\
\hline 6. & Body serum, Bedak & 8 & 6 & $75.00 \%$ \\
\hline 7 & Serum , Shampoo & 8 & 6 & $75.00 \%$ \\
\hline
\end{tabular}

\subsubsection{Pembentukan Aturan Asosiasi}

Dari tahap-tahap yang telah dilakukan sebelumnya memenuhi pola kombinasi 2 itemset, dengan ketentuan minimum support $20 \%$ dan minimum confidance $=70 \%$ maka aturan asosiasi yang terbentuk adalah sebagai berikut:

Tabel 3.8 Aturan Asosiasi Yang Terbentuk

\begin{tabular}{|c|c|c|c|}
\hline No & Aturan & Support & Confidance \\
\hline 1 & Bedak, BB cream & $30.00 \%$ & $90.00 \%$ \\
\hline 2 & Serum, Lipstik & $26.67 \%$ & $100.00 \%$ \\
\hline 3 & $\begin{array}{c}\text { Handbody, Cream } \\
\text { wajah }\end{array}$ & $23.33 \%$ & $100.00 \%$ \\
\hline 4 & Body serum, BB cream & $23.33 \%$ & $87.05 \%$ \\
\hline 5 & $\begin{array}{c}\text { Cream wajah , } \\
\text { Handbody }\end{array}$ & $23.33 \%$ & $77.78 \%$ \\
\hline 6. & Body serum, Bedak & $20.00 \%$ & $75.00 \%$ \\
\hline 7 & Serum, Shampoo & $20.00 \%$ & $75.00 \%$ \\
\hline
\end{tabular}

Dari aturan asosiasi yang terbentuk pada tabel 3.8 maka dapat diambil kesimpulan sebagai berikut :

1. Jika konsumen membeli (Bedak) maka akan dipasangkan bersama (BB cream) dengan Support 30.00\% dan Confidance $90.00 \%$.

2. Jika konsumen membeli (Serum) maka akan dipasangkan bersama (Lipstik) dengan Support $26.67 \%$ dan Confidance $100.00 \%$.

3. Jika konsumen membeli (Handbody) maka akan dipasangkan bersama (Cream wajah) dengan Support 23,33\% dan Confidance 100,00\%.

4. Jika konsumen membeli (Body serum) maka akan dipasangkan bersama (BB cream) dengan Support 23,33\% dan Confidance 87,05\%.

5. Jika konsumen membeli (Cream wajah) maka akan dipasangkan bersama (Handbody) dengan Support 23,33\% dan Confidance 77,78\%.

6. Jika konsumen membeli (Body serum) maka akan dipasangkan bersama (Bedak) dengan Support $20.00 \%$ dan Confidance $75.00 \%$.

Jika konsumen membeli (Serum) maka akan dipasangkan bersama (Body serum) dengan Support $20.00 \%$ dan Confidance $75.00 \%$.

\subsection{Use Case Diagram}

Prosedur sistem akan digambarkan menggunakan UML. Penggabungan UML menggambarkan diagram use case yang selanjutnya setiap proses terjadi akan diperjelas dengan Diagram Activity. 


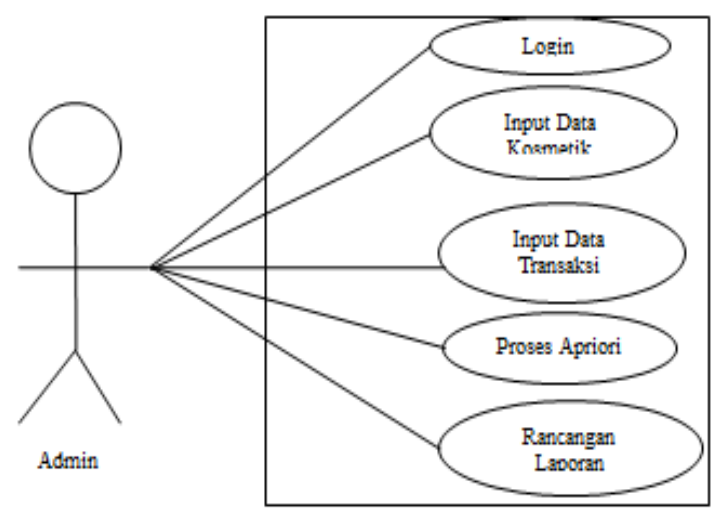

Gambar 3.4 Use Case Diagram

\subsection{Activity Diagram}

Diagram aktivitas atau activity diagram mengambarkan aliran kerja atau aktivitas dari sebuah sistem atau proses bisnis atau menu yang ada pada perangkat lunak. Diagram aktivitas mengambarkan aktivitas sistem bukan apa yang dilakukan aktor, jadi aktivitas dapat dilakukan oleh sistem. Activity Diagram menggambarkan berbagai alir aktifitas dalam sistem yang sedang dirancang untuk mendapatkan strategi promosi pembelian produk.

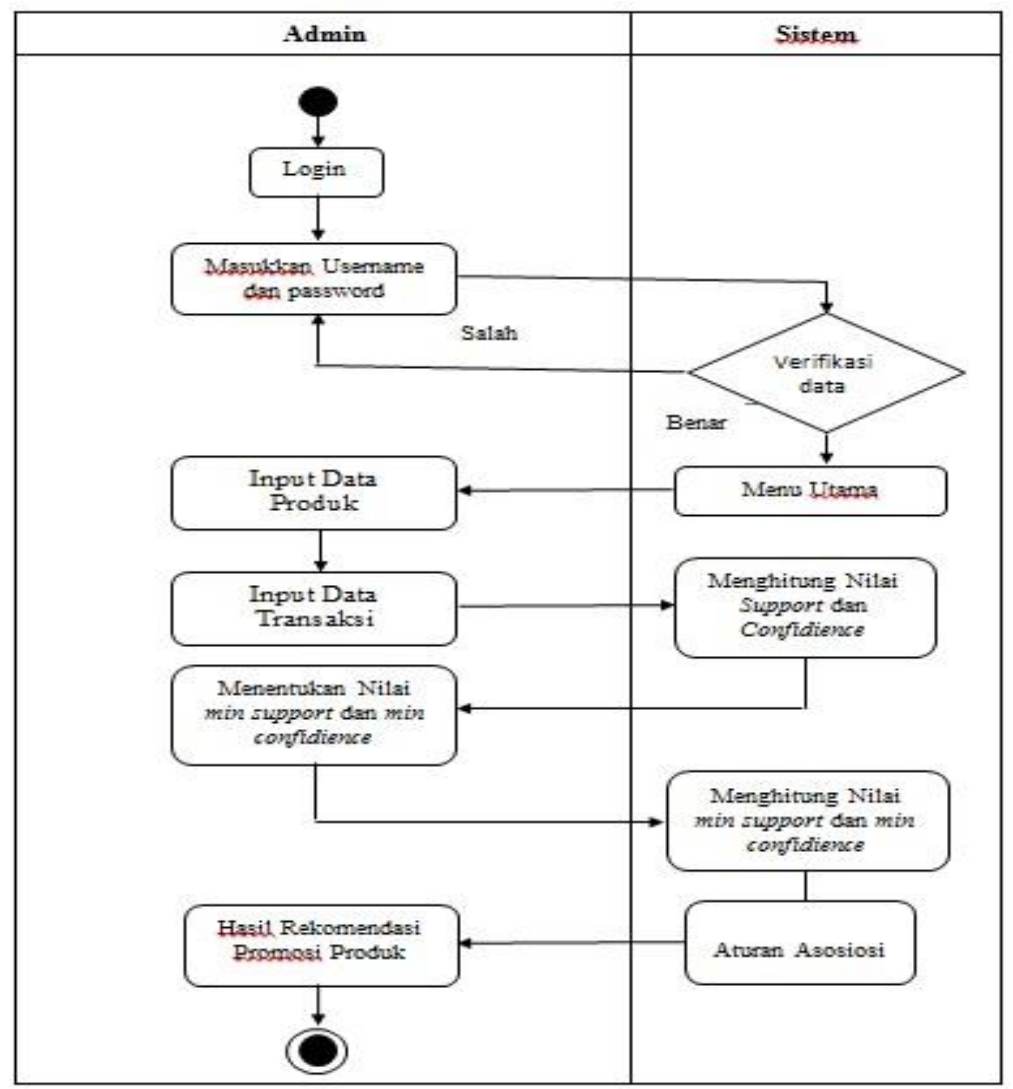

Gambar 3.5 Activity Diagram Activity Diagram 


\subsection{Class Diagram}

Cläss diägramm menggambaarkân strüktür stätiș class didalam aplikasi. Class merepresentasikan sesuatu yang ditangani oleh sistem. Berdasarkan candidate class di atas, maka dapat diketahui terdapat 3 (tiga) buah class yaitu sebagai berikut:

\begin{tabular}{|l|}
\hline \multicolumn{1}{|c|}{ User } \\
\hline - Username \\
- Pessword \\
\hline - Login 0 \\
\hline
\end{tabular}
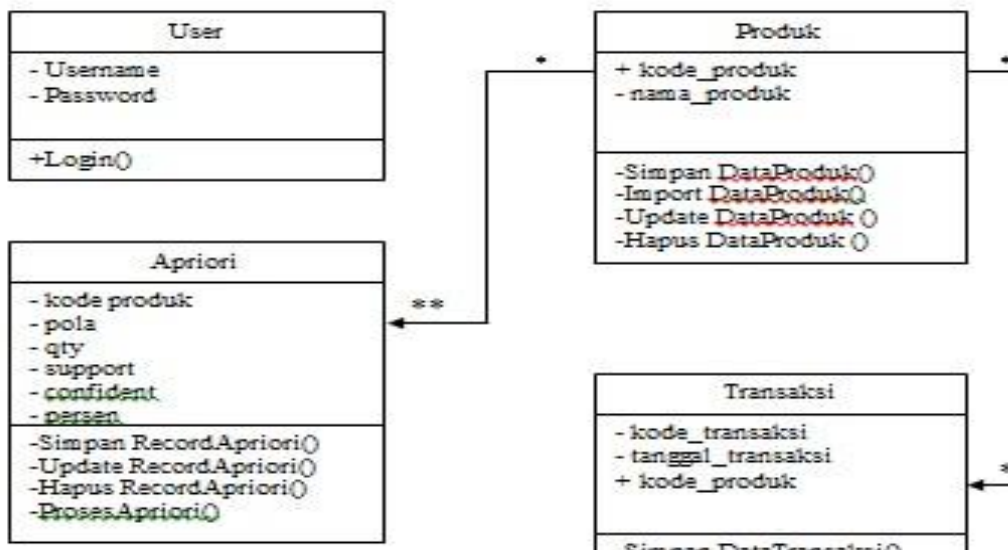

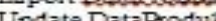

-Hapus DataProduk: 0

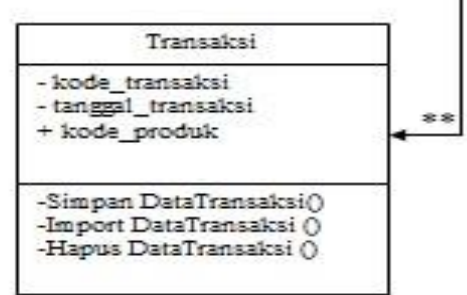

Gambar 3.6 Class Diagram Apriori

\section{IMPLEMENTASI DAN PENGUJIAN}

\subsection{Implementasi Sistem}

Implementasi sistem adalah suatu prosedur yang dilakukan untuk menyelesaikan sistem yang ada dalam dokumen rancangan yang telah disetujui dan mengujinya. Metode pengujian yang di gunakan adalah Metode Apriori yaitu dalam mesin pembelajaran berdasarkan data training, dengan menggunakan probabilitas bersyarat sebagai dasarnya.

Untuk menguji kebenaran dari hasil pemilihan data yang dikerjakan secara manual pada Bab III tersebut di gunakanlah software Microsoft Visual Studio 2008. Berikut dibawah tahap dari pengimplementasian data mining dengan menggunakan metode Apriori.

\subsection{Interface Form Login}

1. Form Login

Tampilan formlogin dapat dipanggil ketika pengguna memilih menu file dan kemudian memilih sub menu file. Dari gambar tersebut diatas terdapat dua textbox yang berfungsi sebagai tempat untuk melakukan inputan username serta password dan dua button yang berfungsi untuk menjadi tombol login dan tombol batal login 


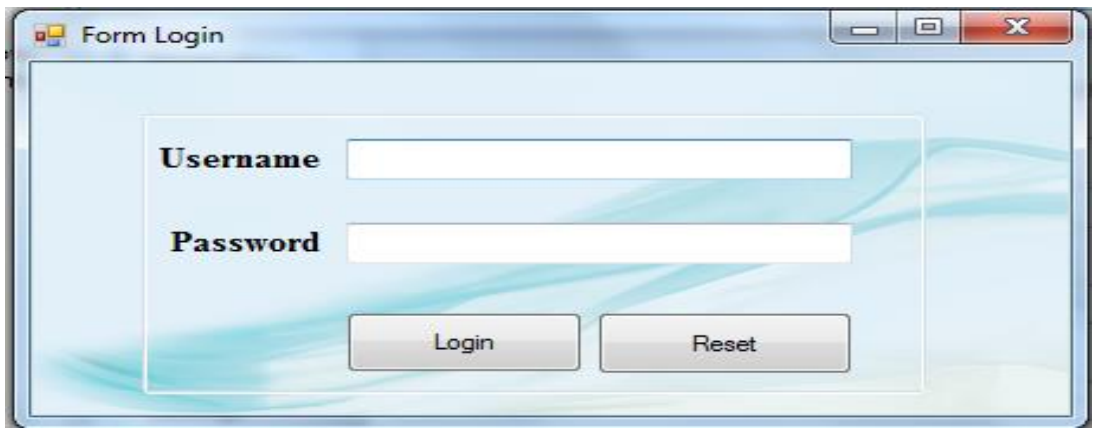

Gambar 4.2 Tampilan interface form Login

Dari gambar tersebut diatas terdapat dua textbox yang berfungsi sebagai tempat untuk melakukan inputan username serta password dan dua button yang berfungsi untuk menjadi tombol login dan tombol batal login

\section{Form Menu Utama}

Pertama kali menjalankan aplikasi maka akan tampil menu utama dimana menu pada menu utama masih belum dapat digunakan karena pengguna belum melakukan login ke sistem.

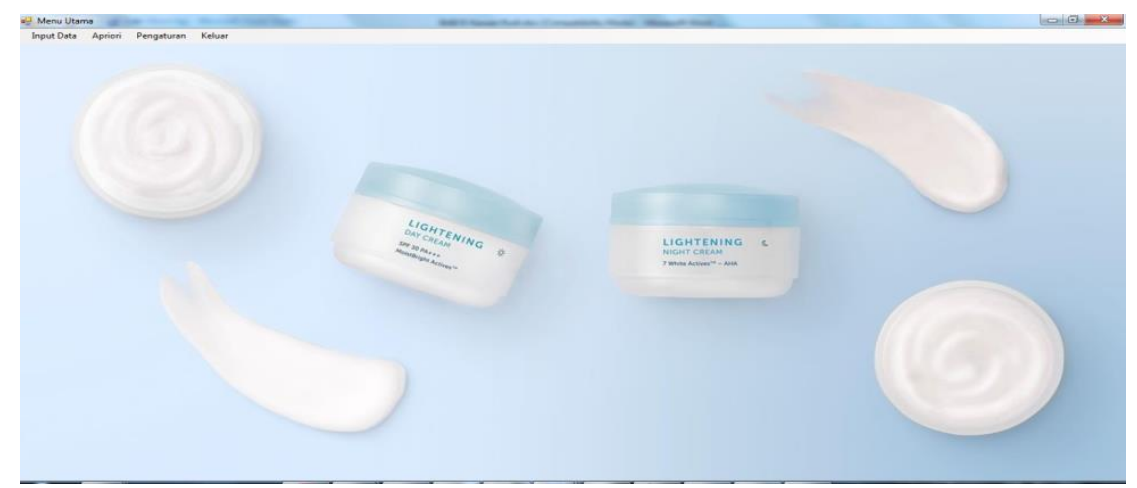

Gambar 4.3 Tampilan interface form Menu Utama

3. Form Data Produk

Form Data Produk adalah Form yang digunakan untuk mengelola Data Data Produk yang ada pada Sistem. 


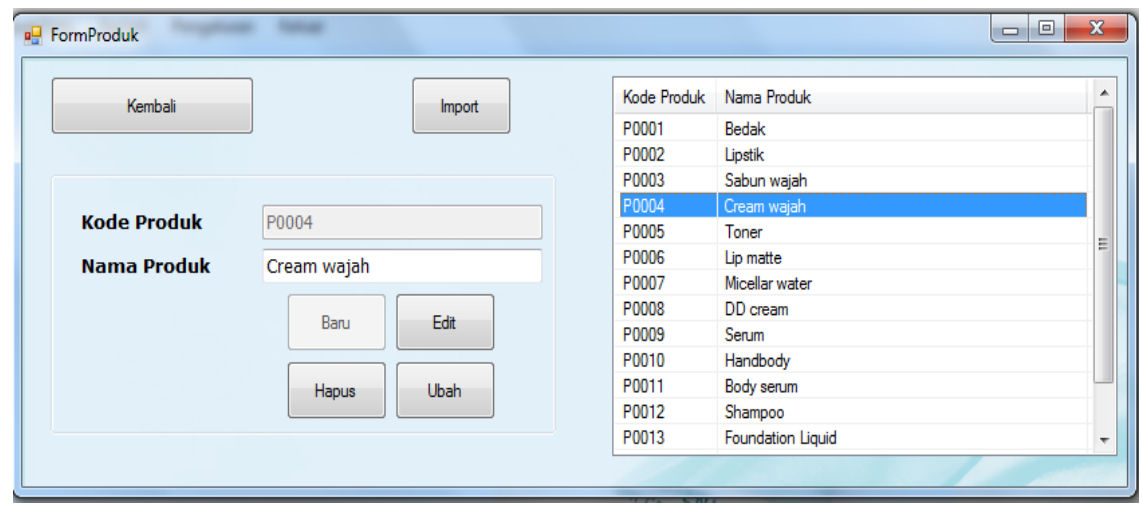

Gambar 4.4 Tampilan interface form Data Produk

4. Form Transaksi

Form Transaksi adalah Form yang digunakan untuk mengelola Data Transaksi

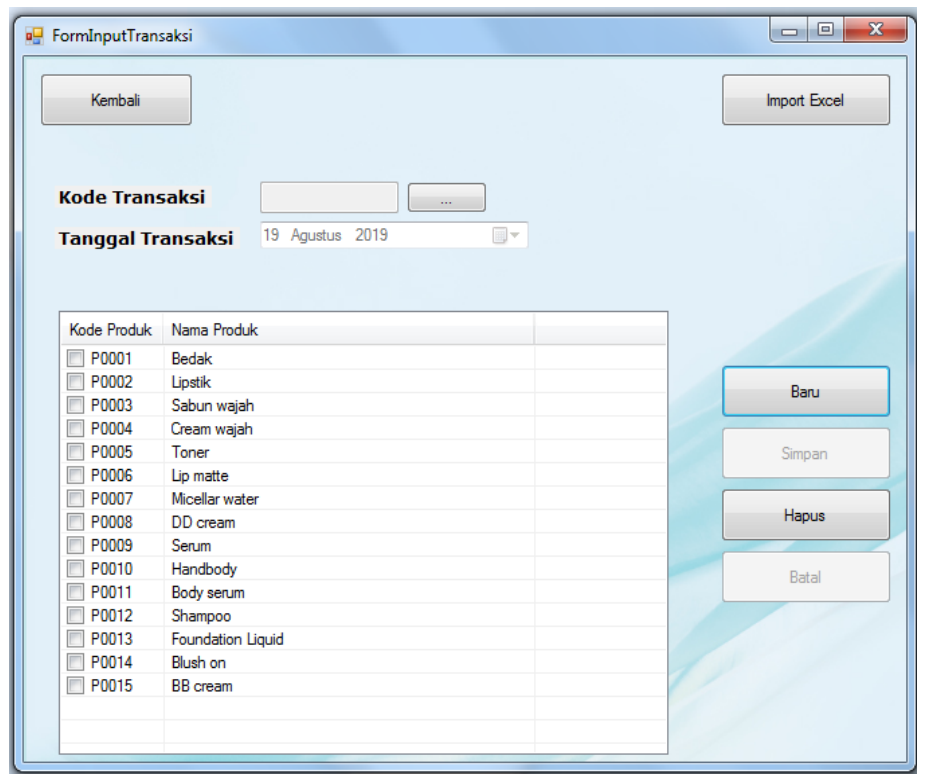

Gambar 4.5 Tampilan interface form transaksi .

4. Form Proses Apriori

Form Proses Apriori adalah Form yang digunakan untuk memproses data transaksi menggunakan algoritma Apriori. 


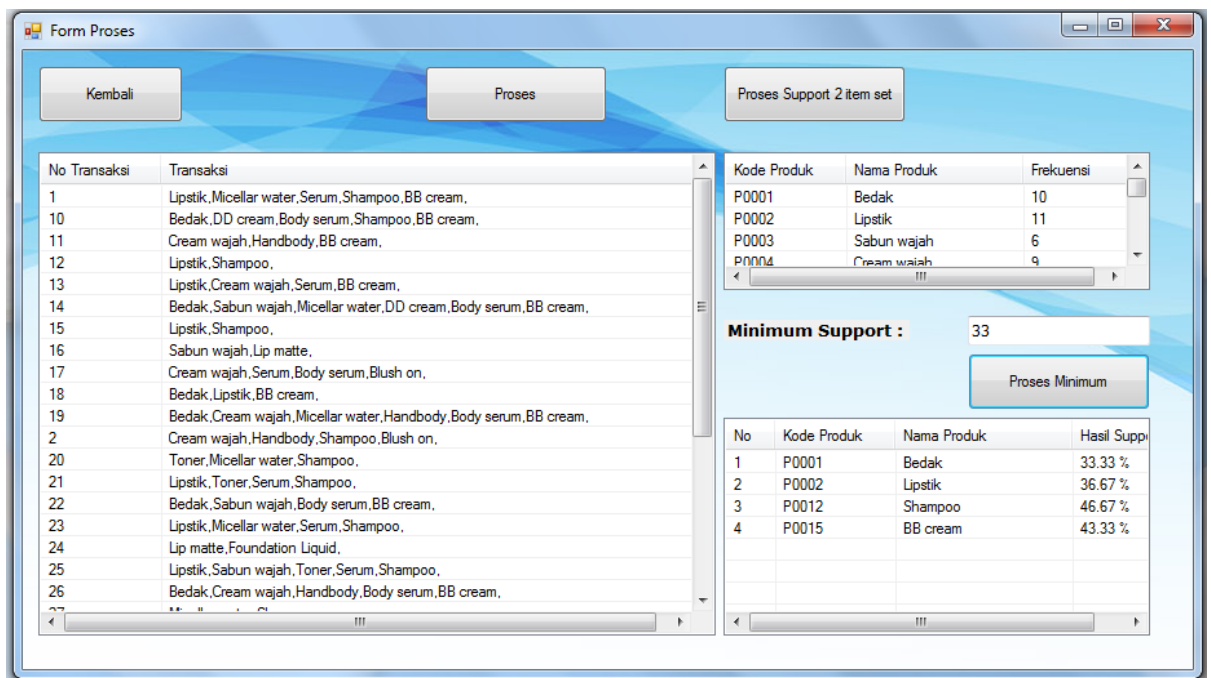

Gambar 4.5 Tampilan interface form proses apriori .

5. Form Proses 2 itemset

Form Proses 2 Itemset adalah Form yang digunakan untuk memproses data transaksi menggunakan algoritma Apriori dengan 2 Itemset.

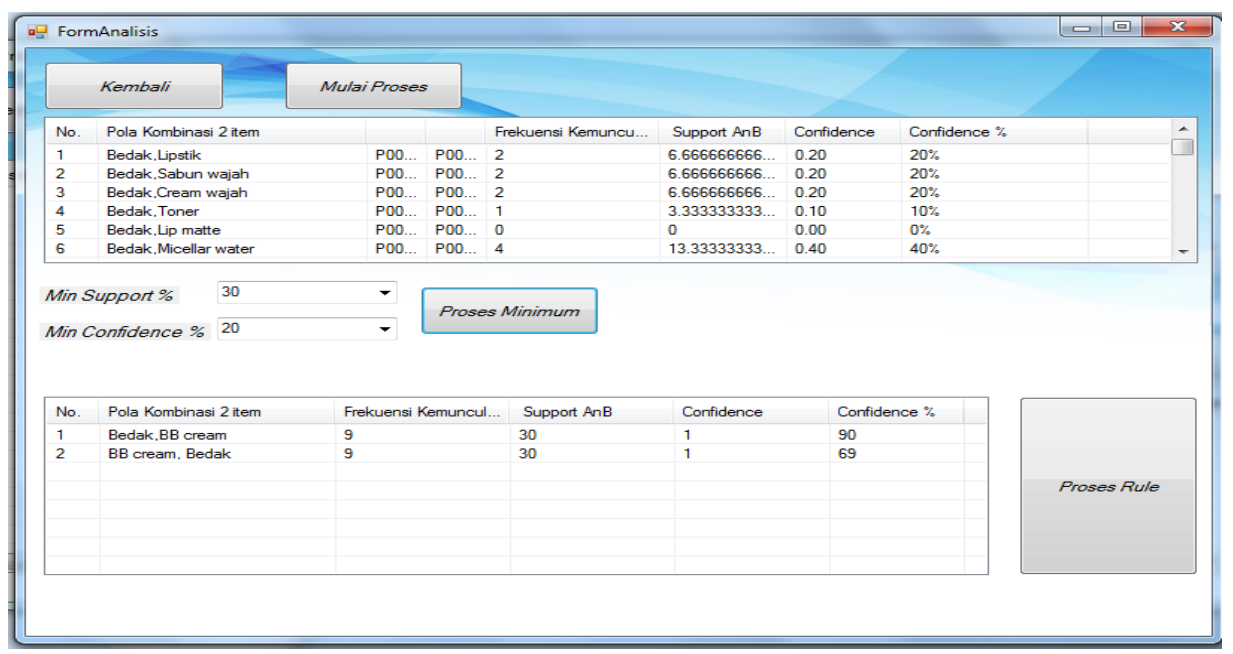

Gambar 4.6 Tampilan interface form Proses 2 itemset

\subsection{Kesimpulan}

Dari hasil penelitian dapat disimpulkan bahwa :

1. Untuk analisis data mining untuk strategi promosi produk wardah kosmetik dengan menggunakan metode apriori dilakukan dengan pemodelan sistem memanfaatkan UML, yaitu Use Case, Activity Diagram dan Class Diagram.

2. Dalam menerapkan data mining strategi promosi produk wardah kosmetik dengan menggunakan metode apriori. 
3. Implementasi data mining strategi promosi produk wardah kosmetik pada aplikasi pemograman Microsoft Visual Studio 2008, dengan menggunakan database Access dan laporan dengan Crystal Report.

\subsection{Saran}

Agar pengembangan sistem kedepannya dapat dirancang dengan pengembangan yang lebih meningkat Khususnya pada mendiagnosa penyakit tanaman mentimun dalam metode Teorema Bayes, beberapa berikut ini saran yang dapat diberikan:

1. Sistem yang dibangun dapat terus dikembangkan untuk mendeteksi penyakit-penyakit yang lain.

2. Hasil perhitungan sebaiknya mencapai target kesamaan yang tinggi berdasarkan referensi masukan dari banyak pakar.

3. Sofware aplikasi diharapkan kedepanya bisa berkembang lebih baik, dalam menentukan diagnosa penyakit tanaman mentimun dengan gejala yang lebih spesifik berdasarkan penyebabnya, misalnya karena penyakit dan hama.

\section{UCAPAN TERIMA KASIH}

Terimakasih diucapkan kepada pihak-pihak yang telah mendukung dalam proses pembuatan jurnal ini yang tidak dapat disebutkan satu per satu. Kiranya bisa memberi manfaat bagi pembacanya dan dapat meningkatkan kualitas jurnal selanjutnya.

\section{DAFTAR PUSTAKA}

- Rambat Lupiyoadi. (2013). Manajemen Pemasaran Jasa (Edisi 2). Jakarta: Salemba Empat.

- Sani, S,. \& Dedy, S. (2010). Pengantar Data Mining Menggali Pengetahuan Dari Bongkahan Data. Yogyakarta:Andi.

- Rossa A.S,. \& Shalahuddin, (2015). Rekayasa Perangkat Lunak. Bandung:Informatika.

- Purwadi., Puji, S.R., \& Nurdiyanti, S. 2019. Penerapan Data Mining Untuk Menggali Laju Pertumbuhan Penduduk Menggunakan Redresi Liear Berganda. Sains dan Komputer, (18) 1, 55-61.

- Alfin, K., Ivana., Eka, P., Calvin W., Vinrick, W., \& Albert. 2019. Pengaruh Promosi Penjualan Dan Harga Terhadap Keputusan Konsumen. Aksara Public (3) 1, 102-113.

- Alfiqra., \& Faiza, Y.A. 2018. Penerapan Market Basket Analysis Menggunakan Proses KDD Sebagai Strategi Penjualan Produk Swalayan. Seminar Nasional, 509-516.

- Kennedi T., Hoga, S., \& Bobby, R. 2013. Implementasi Data Mining Algoritma Apriori Pada Sistem Persedian Alat Kesehatan. Informasi dan Teknologi IImiah, (1) 1, 93-106.

- Mateus, P.G., Fitri, M., \& Indra, D.W. 2018. Penerapan Metode Data MiningBasket Analysis Terhaap Data Penjualan Produk Menggunakan Algoritma Apriori. Jurnal Informatika Merdeka Pasuruan, (3) 2, 17-22.

- Puspa, S., Bosker, S. 2018. Aplikasi Data Mining Mengguakan Algoritma Apriori Untuk Penjualan Produk Terbesar. Mantik Panusa, (222) 1, 34-38.

- Purwadi., Puji, S.R., \& Nurdiyanti, S. 2019. Penerapan Data Mining Untuk Menggali Laju Pertumbuhan Penduduk Menggunakan Redresi Liear Berganda. Sains dan Komputer, (18) 1, 55-61.

- Muhammad, I. 2019.Implementasi Data Mining Dengan Algoritma Naive Bayes Untuk Memprediksi Angka Kelahiran. Jurnal Pelita Informatika, (18) 1, 160-167.

- Sriyuni, S., \& Amir, M.H. 2019. Penerapan Algoritma Apriori Dalam Data Mining Untuk Memprediksi Pola Pengunjun. Jurnal Teknologi dan Ilmu Komputer Prima, (2) 1, 49-54. 